\title{
Biological roles of cysteine proteinases in the pathogenesis of Trichomonas vaginalis
}

\author{
Hilda M. Hernández*, Ricardo Marcet, and Jorge Sarracent \\ Parasitology Department, "Pedro Kourí" Tropical Medicine Institute, Havana 10400, Cuba
}

Received 5 February 2014, Accepted 9 October 2014, Published online 28 October 2014

\begin{abstract}
Human trichomonosis, infection with Trichomonas vaginalis, is the most common non-viral sexually transmitted disease in the world. The host-parasite interaction and pathophysiological processes of trichomonosis remain incompletely understood. This review focuses on the advancements reached in the area of the pathogenesis of $T$. vaginalis, especially in the role of the cysteine proteinases. It highlights various approaches made in this field and lists a group of trichomonad cysteine proteinases involved in diverse processes such as invasion of the mucous layer, cytoadherence, cytotoxicity, cytoskeleton disruption of red blood cells, hemolysis, and evasion of the host immune response. A better understanding of the biological roles of cysteine proteinases in the pathogenesis of this parasite could be used in the identification of new chemotherapeutic targets. An additional advantage could be the development of a vaccine in order to reduce transmission of T. vaginalis.
\end{abstract}

Key words: Trichomonas vaginalis, Trichomonosis, Cysteine proteinases, Pathogenesis.

\begin{abstract}
Résumé - Rôles biologiques des cystéine-protéases dans la pathogenèse de Trichomonas vaginalis. La trichomonose humaine, infection par Trichomonas vaginalis, est la maladie sexuellement transmissible nonvirale la plus courante dans le monde. L'interaction hôte-parasite et les processus physiopathologiques de la trichomonose restent mal compris. Cette revue se concentre sur les progrès obtenus dans le domaine de la pathogenèse de T. vaginalis, spécialement le rôle des cystéine-protéases. Elle met en lumière les différentes approches dans ce domaine et donne la liste d'un groupe de cystéine-protéases de $T$. vaginalis impliquées dans des processus divers tels que l'invasion de la couche de mucus, la cytoadhérence, la cytotoxicité, la disruption du cytosquelette des globules rouges, l'hémolyse et l'échappement envers la réponse immunitaire de l'hôte. Une meilleure compréhension des rôles biologiques des cystéine-protéinases dans la pathogenèse de ce parasite pourrait être utile pour l'identification de nouvelles cibles chimiothérapeutiques. Un avantage supplémentaire pourrait être le développement d'un vaccin en vue de réduire la transmission de $T$. vaginalis.
\end{abstract}

\section{Introduction}

Cysteine proteinases $(\mathrm{CPs})$ from a variety of parasites such as Plasmodium falciparum [42], Trypanosoma cruzi [38], Entamoeba histolytica [79], Leishmania (Viannia) braziliensis [82], and Trichomonas vaginalis [81] have been characterized at molecular and cellular levels, and the function that proteinases play in these organisms is coming into focus [56]. Important roles have been proposed for CPs in diverse processes such as cytotoxicity, cytoadherence, metabolism, host cell invasion, molecule degradation, virulence factors, hemolysis, and host immune response evasion, among others [75, 89].

\footnotetext{
*Corresponding author: hilda@ipk.sld.cu
}

Trichomonas vaginalis is a parasitic protozoan that causes human trichomonosis, a sexually transmitted disease. This parasite is a major cause of vaginitis, cervicitis, urethritis, and prostatitis $[17,69]$. The consequences for women with trichomonosis include enhanced risk for human immunodeficiency virus transmission [53], cervical cancer [1], and adverse pregnancy outcomes, which suggest a need for increased control efforts [88].

Trichomonas vaginalis infection is very complex, and the broad ranges of clinical symptoms are unlikely to be attributed to a single pathogenic process [86]. The exact mechanisms of the pathogenesis have not been clearly elucidated to date [92]. However, the sequencing of the $T$. vaginalis genome has led to knowledge of new gene families involved in the host 
pathogenesis, leading to new research to understand the mechanism of the parasite's pathogenicity better [19]. Trichomonal cytoadherence to epithelial cells is a critical step in the initiation phase of the infection and subsequent pathogenesis [31]. This process is species-specific and capable of inducing gene upregulation not only in the parasite [57] but also in the host cell [58].

Trichomonas vaginalis possesses high levels of proteolytic activity, mainly of the CP type. Interestingly, up to 23 spots with proteolytic activity between 23 and $110 \mathrm{kDa}$ have been detected using two-dimensional (2-D) substrate gel electrophoresis (zymograms) [74]. Additionally, Leon-Sicairos et al. demonstrated that more spots with proteolytic activity can be observed on the zymograms depending on the parasite's in vitro growth conditions, especially iron concentration [67]. However, most of these spots are encoded by only nine distinct genes [80]. Currently, this parasite is estimated to contain in the order of 156 cysteine peptidases [51].

Despite the studies related to the trichomonad proteinases, only a few CPs have been identified and characterized. Nevertheless, the roles of some of them in the onset of the infection have been demonstrated $[8,13,45,70]$. The parasite's cysteine proteolytic activity is necessary for recognition and adhesion of the parasite to the epithelial cells of the host [51].

In this review, we examine the advances in the understanding of the importance of CPs in the pathogenesis exerted by T. vaginalis. There are numerous events in the parasite's development where the contribution of CPs has been hinted at, but the enzymes involved have not been elucidated. Studies are now underway to characterize the specific roles of the trichomonad CPs in the pathogenesis better. The scope of this review encompasses biological processes where the involvement of these enzymes in the pathogenesis has been suggested.

\section{Pathogenesis}

Trichomonad CPs are found in different cell compartments, i.e., lysosomes and plasma membranes, or even released into the culture medium through the lysosome and late/ endosomal pathways [87]. In vivo, trichomonad CPs have been found in the vaginal secretions of patients with acute trichomonosis [39, 50, 70, 81, 98], and some of them are immunogenic $[4,5]$. Some CPs have been involved in virulence mechanisms (Table 1).

\section{Invasion of the mucous layer}

The mucous layer of the genital tract is the first host surface encountered by trichomonads. Mucin, the major proteinaceous constituent of mucous, forms a lattice structure that serves as a formidable physical barrier to microbial invasion. Binding the parasite to mucin followed by its proteolytic degradation by mucinase appears to be the major mechanism by which $T$. vaginalis can gain access to the underlying epithelium. Five mucinases of identical molecular weight were found in trichomonad lysates and supernatants. These mucinases are cysteine-like peptidases [65].

Given that the urogenital region of women is a constantly changing environment, it is conceivable that interactions of trichomonads with mucin and/or vaginal epithelial cells fluctuate [5] and persist in a non-self-limiting fashion [43]. For example, hormones influence the exfoliation of the squamous vaginal epithelial cells and, in addition, the trichomonad cysteine proteinase released into the vaginal milieu [5] may contribute to desquamation of the vaginal and cervical epithelial tissue [98]. This local erosion permits the parasites access to extracellular matrix-basement membrane components, such as fibronectin, lamimin binding, $\alpha$-actinin, enolase, and phosphoglucomutase, that in parallel plays a role in cytoadherence $[3,59]$.

\section{Cytoadherence}

The adherence mechanism to mucin may allow trichomonads to gain a temporary foothold before penetration into the mucous layer and ultimate parasitism of the underlying epithelial cells. Adherence to host surfaces has been shown to be an early and critical step in Trichomonas pathogenesis [14]. Five trichomonad surface proteins, named adhesins (AP23, AP33, AP51, AP65, and AP120) [6, 14, 41, 63, 72], mediate adherence and these molecules are upregulated during attachment to vaginal epithelial cells $[15,41]$. During this event, T. vaginalis perturbs the junctional complex in epithelial cells, producing a decrease in the transepithelial electrical resistance, alteration in the pattern of functional complex protein distribution, as was observed for E-cadherin and ZO-1, and enlargement of the spaces between epithelial cells. These effects were dependent on the parasite's virulence, the expression of adhesion proteins on the parasite's surface and the iron concentration in the medium [26]. Iron plays a critical role in the host-parasite interaction and modulates the expression of virulence factors in this protozoan [94]. Fluorescence and immuno-cytochemical experiments showed that highiron-grown organisms coexpressed adhesins on the surface and intracellularly, in contrast with low-iron-grown parasites [41]. In concordance, in iron-depleted parasites, enzymes involved in energetic metabolism, proteolysis and hydrogenosomal iron-sulfur $(\mathrm{Fe}-\mathrm{S})$ proteins were downregulated or even suppressed. Thus, the iron modulates the expression of proteins in the parasite [29]. In addition, $\mathrm{Zn}^{2+}$ also affects the protein profile of $T$. vaginalis. Some proteins were up- or downregulated in the presence of $\mathrm{Zn}^{2+}$, while others showed no changes. T. vaginalis differentially expresses 27 proteins in the presence of $\mathrm{Zn}^{2+}$, which suggests that this parasite has the capability to adapt to different environments. These differences in protein expression profiles correlated with changes in some of its virulence properties, such as cytotoxicity [96].

Interestingly, an analysis by mass spectrometry indicated that the 48- and 63-kDa proteins of $T$. vaginalis had identity with two adhesins: AP51 and AP65, respectively. This confirms the existence of multifunctional proteins in $T$. vaginalis, and suggests that AP51 and AP65, besides serving as adhesion molecules, could also act as heme- and hemoglobin-binding proteins [11]. Moreover, it has been demonstrated that the adhesin AP120 showed homology with a hydrogenosomal enzyme, the pyruvate ferredoxin oxidoreductase encoded by the pfoa gene. This homology suggests that this novel adhesin induced by iron could also be an example of a moonlighting 
Table 1. Virulence mechanisms that involve cysteine proteinases in Trichomonas vaginalis.

\begin{tabular}{ll}
\hline Virulence mechanisms & \multicolumn{1}{c}{ References } \\
\hline Invasion of the mucous layer & Lehker \& Sweeney (1999) [65] \\
Cytoadherence & Arroyo \& Alderete (1989, 1995); Mendoza-López et al. (2000); Hernández \\
& et al. (2004) [12, 13, 49, 70] \\
Cytotoxicity & Alvarez-Sánchez et al. (2000, 2007, 2008); Hernández-Gutíerrez et al. \\
& $(2003,2004) ;$ Kummer et al. (2008); de Jesus et al. (2009); Ramón-Luing \\
& et al. (2011) [8-10, 28, 45, 46, 60, 81] \\
Cytoskeleton disruption of red blood cells and hemolysis & Dailey et al. (1990); Fiori et al. (1993, 1997) [27, 36, 37] \\
Degradation of immunoglobulins & Provenzano \& Alderete (1995); Hernández-Gutierrez et al. (2004) [45, 78] \\
Apoptosis & Chang et al. (2004, 2006); Sommer et al. (2005); Kang et al. (2006); \\
& Fichorova (2009) [24, 25, 32, 55, 91] \\
\hline
\end{tabular}

protein in T. vaginalis [72]. Thus, it will be interesting to identify other alternative functions for these trichomonad proteins.

An iron-responsive promoter and other regulatory elements in the 5'-UTR of the AP65-1 gene were identified as a mechanism for the positive transcriptional regulation of trichomonad genes by iron [76]. Recently, two IRE (iron-responsive elements)-like hairpin-loop structures in mRNAs of differentially iron-regulated TVCP4 and TVCP12 cysteine proteinases, as well as IRP (iron regulatory proteins)-like trichomonad proteins were identified in $T$. vaginalis. These data suggested the existence in this protozoan of a post-transcriptional iron regulatory mechanism by an IRE/IRP-like system [90].

One report indicates that the reduced amounts of putrescine by inhibition of ornithine decarboxylase (ODC) significantly increased $T$. vaginalis adherence to vaginal epithelial cells mediated by protein adhesions. However, surprisingly and unexpectedly, trichomonal contact-dependent cytotoxicity was absent [40]. Recently, this effect was demonstrated by cytotoxicity and cell-binding assays followed by zymograms, as well as Western blot and indirect immunofluorescence assays using a specific anti-CP65 antibody to detect CP65 [9]. Trichomonads grown in the presence of the ODC inhibitor, 1-4 diamino-2-butanone, had lower levels of cytotoxicity that corresponded with diminished CP65 proteolytic activity when compared with untreated organisms handled identically. It was reversed by addition of exogenous putrescine, showing a direct link between polyamine metabolism and expression of the cytotoxic CP65 proteinase in the involved trichomonal host cellular damage [9].

Furthermore, it was demonstrated that trichomonad proteinase activity appears to be necessary for cytoadherence [12]. The protease inhibitors $N$ - $\alpha$ - $p$-tosyl-L-lysine-chloromethyl ketone $\mathrm{HCl}$ (TLCK) and leupeptin were found to significantly reduce parasite to cervical adenocarcinoma (HeLa) cells and vaginal epithelial cells [12]. Exposure of TLCK-treated microorganisms to other cysteine proteinases restored cytoadherence levels, indicating that proteinase action on the parasite's surface is a prerequisite for host cell attachment [13]. The exact function or the precise step for trichomonad proteinase involvement during parasite recognition and binding to epithelial cell surfaces is not known [12]. It is conceivable that unmasking of adhesins by proteinases residing on the parasite's surface is required for host cell recognition and binding. It is equally possible that adhesins on trichomonad membranes exist as precursor forms which must be activated by specific proteinase digestion [12].

Using a cell-binding assay, a TLCK-sensitive 30-kDa cysteine proteinase with high affinity for the surface of cervical adenocarcinoma (HeLa) cells was identified in $T$. vaginalis extracts $[13,70]$. A specific anti-CP30 antibody reduced cytoadherence by up to $50 \%$. In addition, it was demonstrated that patients with trichomonosis possess antibodies to CP30 in both sera samples and vaginal swabs [70]. More recently, CP30 activity was found in all the vaginal washes of symptomatic women and in $80 \%$ of the vaginal washes of asymptomatic women [98]. Probably, besides CP30, other factors such as CP65, CP39, and CP62 may also play a role in leading to symptomatic infection [98]. CP30 was also detected in all the fresh culture isolates from symptomatic and asymptomatic women. This proteinase may be an important virulence factor of the parasite as its expression has been found to be higher in isolates causing symptomatic infection [99].

Recently, a proteomic analysis of $T$. vaginalis protein extracts was performed by Ramón-Luing et al. [80]. Nine CPs were identified in the $30-\mathrm{kDa}$ region (TVCP1, TVCP2, TVCP3, TVCP4, TVCP4-like, TVCP12, TVCPT, TVLEGU-1, and another legumain-like CP). By two-dimensional Western blot, four papain-like CPs (TVCP2, TVCP4, TVCP4-like, and TVCPT), and one legumain-like CP (TVLEGU-1) showed the major reactive spots to $T$. vaginalis-positive patient sera. These data show that some CPs could be potential biomarkers for serodiagnosis of trichomonosis [80]. Recently, Rendón-Gandarilla et al. showed that TVLEGU-1 is a surface proteinase upregulated by iron, with affinity for the surface of cervical adenocarcinoma (HeLa) cells, that plays a major role in trichomonal cytoadherence. Hence, TVLEGU-1 is a novel virulence factor of T. vaginalis that is also released in vaginal secretions during infection [83].

Cuervo et al. performed a small-scale comparative analysis of soluble protein expression between $T$. vaginalis isolates exhibiting low- and high-virulence phenotypes. These analyses identified both quantitative and qualitative differences in protein expression profiles, including a number of proteins involved in carbohydrate and energy metabolism, cytoskeletal structure, and proteolysis [22]. Further, de Jesus et al. identified eight CPs that were differentially expressed between high- and low-virulence phenotypes. Seven of the eight CPs identified belong to Clan CA, family $\mathrm{C} 1$, cathepsin L-like $\mathrm{CP}$, and one 
belongs to Clan $\mathrm{CD}$, family $\mathrm{C} 13$, asparaginyl endopeptidaselike CP. A BLAST analysis followed by CLUSTAL alignment of amino acid sequences of differentially expressed CPs showed identity or high homology to the previously described $\mathrm{CP}$ cDNA clones $\mathrm{CP} 1, \mathrm{CP} 3$, and $\mathrm{CP} 4$, and to a secreted $\mathrm{CP}$ fraction of $30 \mathrm{kDa}$ involved in apoptosis of vaginal epithelial cells [28].

In a study performed by our group, it was shown that antiCP62 monoclonal antibodies (4D8 and 1A8) decrease cytoadherence of $T$. vaginalis to the cervical adenocarcinoma (HeLa) cell monolayer. The injection of these monoclonal antibodies into BALB/c mice by the intraperitoneal route conferred different protection levels against a challenge with the parasite [49]. Moreover, no cytotoxic effect of the monoclonal antibodies against the parasite was detected by monitoring the lactate dehydrogenase release by $T$. vaginalis in response to different antibody concentrations. On the other hand, anti-CP62 monoclonal antibodies were unable to inhibit the CP activity of T. vaginalis. These results suggest that the epitopes recognized by these antibodies are important in $T$. vaginalis cytoadherence and that the secreted proteinase shares epitopes with some structure in the parasite's surface that is necessary for cytoadherence [49]. Another specific anti-CP TVLEGU-1 antibody can decrease the cytoadherence by inhibition of $\mathrm{CP}$ activity [83].

Further studies showed that anti-CP62 monoclonal antibodies (4D8 and 1A8) react with a different protein epitope of a repetitive nature found on CP62 and this could explain the differences among them in the protection grade obtained in the challenge experiments [48]. In addition, the intranasal immunization of mice with CP62 combined with cholera toxin or $\mathrm{CpG}$ adjuvant induced high levels of a specific anti-CP62 antibody in serum and vaginal secretions, and conferred protection against T. vaginalis [47]. Recently, CP62 was detected in all the vaginal swabs from symptomatic and asymptomatic women screened. Significant amounts of antigens were detected in vaginal swabs from symptomatic when compared with asymptomatic women, indicating that $\mathrm{CP} 62$ could be a virulence factor [50]. It will be interesting to determine the functions of $\mathrm{CP} 62$, and the environmental conditions that modulate their expression and possible participation in T. vaginalis cytopathogenicity.

Besides CPs, other surface domains such as lipophosphoglycan are also responsible for adherence of trichomonads to human vaginal epithelial cells. T. vaginalis lipophosphoglycan triggers a selective upregulation of cytokines by human female reproductive tract epithelial cells which promotes the adhesion and transmigration of neutrophils across the endothelium, and the macrophage inflammatory protein $3 \alpha$, which is a chemoattractant for immune cells and is essential for dendritic cell maturation [35]. Another study has demonstrated that T. vaginalis LPG mutants reduced adherence to human ectocervical epithelial cell lines [16].

\section{Cytotoxicity}

Evidence suggests that $T$. vaginalis may produce molecules that are delivered to target cells and mediate cytotoxicity through damage of the plasma membrane [8]. A specific anti-CP65 antibody of $T$. vaginalis reduced cytotoxicity to the cervical adenocarcinoma (HeLa) cell monolayer by up to $64 \%$ [8]. This has also been demonstrated for the CP39 proteinase. Parasites preincubated with the specific antibody to CP39 proteinase exhibited a reduction in their ability to destroy the cervical adenocarcinoma (HeLa) cell monolayer but not in cytoadherence, in a concentration-dependent manner [46]. This proteinase has been suggested as a potential biomarker for trichomonosis [81].

Under iron-restricted conditions there is an increase in the levels of trichomonal cytotoxicity over the cervical adenocarcinoma (HeLa) cell monolayer due to an increase in the TVCP65 proteolytic activity [10]. Likewise, an increase in the secreted CPs from the 30-kDa region (TVCP2, TVCP3, TVCP4, and TVCPT) was also observed, favoring their ability to induce human vaginal epithelial programmed cell death [60]. By a semiquantitative reverse transcription-polymerase chain reaction using mRNA from parasites grown in different iron concentrations, differences in the expression of some of the CP genes were also observed; some of them showed more transcript in iron-restricted conditions (TVCP12 and TVCP65), others in iron-rich conditions (TVCP4). These data suggested that different proteinases with similar molecular weight but different pIs are differentially regulated by iron and participate in virulence properties, such as cytoadherence, cytotoxicity, induction of apoptosis, and other still unknown functions [94].

Recent studies indicated that pretreatment of parasites with the specific Clan CA papain-like CP inhibitor 1-3-carboxy-2,3trans-epoxypropionyl-leucylamido(4-guanidino) butane (E-64) drastically reduced the cytotoxic effect, suggesting that T. vaginalis papain-like CPs are the main factors involved in the cellular damage [28].

\section{Cytoskeleton disruption of red blood cells and hemolysis}

Trichomonas vaginalis has evolved multiple mechanisms for acquiring iron from specific iron-binding (lactoferrin) and iron-containing (hemoglobin and cytochrome) proteins [61]. The iron, which is an important nutrient for $T$. vaginalis, may be obtained by hemoglobin degradation after the lysis of erythrocytes [64]. Identification of a $60-\mathrm{kDa} \mathrm{CP}$ of $T$. vaginalis, which is capable of degrading hemoglobin into heme and globin, supports the supposition that this parasite may use hemoglobin as a source of iron [71].

Metabolically active parasites are necessary for lysis of erythrocytes [36]. CP inhibitors greatly reduced erythrocyte lysis, which suggests that CPs may be a lytic factor involved in hemolysis [27]. The lysis of the erythrocytes appears to be mediated by protein receptors on the surfaces of erythrocytes and parasites. Empirical evidence from studies with human erythrocytes suggests that perforin-like proteins (possibly cysteine proteinase) may be involved [37]. Carlton et al. identified 12 genes (TVSaplip1 to TVSaplip 12) containing pore-forming domains. TVSaplips are similar to amoebapore proteins secreted by Entamoeba histolytica and are candidate trichopores that mediate a cytolytic effect [19]. 
The mechanism of pore formation has been extensively studied in E. histolytica [44]. Acid $\mathrm{pH}$ causes the protonation of the basic His 75 residue that in turn triggers amoebapore dimerization as a result of the interaction of histidine with a negatively charged residue. The interaction of the three amoebapore dimers leads to the formation of a hexameric ring-like structure with a hydrophobic external surface and a hydrophilic inner channel [66]. T. vaginalis-mediated hemolysis is also triggered by an acidic $\mathrm{pH}$ and several TVSaplip domains show a basic His or Lys residue in the same key position as His of amoebapores, suggesting a conserved $\mathrm{pH}-$ dependent mechanism driving oligomerization [51].

Hemolysis seems to occur in three steps: a specific ligandreceptor interaction allows the trichomonad to attach itself to the erythrocytes, followed by the release of perforin-like proteins which form pores in the erythrocyte membrane. Finally, T. vaginalis detaches itself from the cell and cell lysis occurs [37].

\section{Evasion of the host immune response}

The numerous CPs synthesized by T. vaginalis contribute significantly to immune evasion. The parasite's ability to evade the host immune system is an important aspect of the pathogenesis. Avoidance of complement is used by T. vaginalis to overcome the human immune system. T. vaginalis has the advantage of living in a niche in which little complement is present [6]. Nevertheless, iron upregulates the expression of $\mathrm{CPs}$, which have been found to degrade the $\mathrm{C} 3$ portion of complement on the surface of the organism; this allows the organism to evade complement-mediated destruction [6]. However, the particular proteinases responsible for this function have not been identified yet.

In addition, $T$. vaginalis displays other ways of evading the immune system. Provenzano and Alderete reported that numerous CPs secreted by $T$. vaginalis degrade IgG, IgM, and IgA, which allows the organism to survive the antibody response. Degradation of the heavy chain of $\operatorname{IgG}$ and $\operatorname{IgA}$ was observed following incubation with lysates and culture supernatants of T. vaginalis [78]. Among the CPs, TVCP39 is one of the papain-like proteinases that correspond to a single proteolytic spot of $39 \mathrm{kDa}$ and pI 4.5 in 2-D substrate gel electrophoresis. It degrades several extracellular matrix proteins (including fibronectin, different types of collagen, immunoglobulin $\mathrm{G}(\mathrm{IgG})$ and $\operatorname{IgA})$ and hemoglobin [45].

Moreover, secretory leukocyte protease inhibitor (SLPI) is a factor protecting the mucosal surface of the vagina [62]. Again, trichomonad proteinases are able to degrade SLPI and render it non-functional. In symptomatic women, this anti-inflammatory mediator was lower, possibly due to digestion by Trichomonas cysteine proteases [2]. Interestingly, SLPIs have also been shown to prevent HIV transmission, thus trichomonad proteinases may be partly responsible for the observed increase in risk of HIV acquisition in women with trichomonosis [93]. Recently, Huppert et al. showed that in adolescents and young adult females a depressed secretory leukocyte protease inhibitor (SLPI) level is strongly associated with $T$. vaginalis infections in a manner dependent on parasite load [54]. Moreover, experimental studies have proven that SPLI production by vaginal and cervical epithelial cells decreased in response to purified T. vaginalis LPG [33] and thus the lower SLPI levels observed clinically may be due to LPG and not just cystein proteases [34].

Lactobacilli are responsible for maintaining the acidic $\mathrm{pH}$ of the vagina (normal vaginal $\mathrm{pH}$ ) and are considered protective of normal vaginal flora. Hydrogen peroxide produced by lactobacilli readily neutralizes the CPs, showing the protective effect of lactobacilli normal flora [7]. However, both an increase in the vaginal $\mathrm{pH}$ and reduction of the flora have been reported in patients with trichomonosis. This may be caused by phagocytosis of lactobacilli, which would enable the parasite to survive in a more basic milieu, subverting this host protective effect [84].

In addition, the $T$. vaginalis cysteine proteases including CP30 induce apoptosis in vaginal epithelial cells [91] and in multiple mucosal immune cell types [32]. In T cells, macrophages and dendritic cells, T. vaginalis led to apoptosis and production of immunosuppressive cytokines (IL-10, TGF $\beta$ ) [25]. T. vaginalis proteins (adhesins and CP30) induce caspase-mediated apoptosis and immunosuppressive cytokine response [24]. T. vaginalis-induced apoptosis in neutrophils has been linked to caspase-3 activation and reduced expression of the anti-apoptotic protein myeloid cell leukemia sequence 1 (Mcl-1) [55], and in macrophages it has been linked to extracellular signal-regulated kinase activation [23]. T. vaginalis infection has been shown to activate toll-like receptors (TLR)-4 by inducing undefined substance(s) released in the vaginal secretions [101]. To date, trichomonad ligands for TLR4 have not been identified. T. vaginalis infections of the mucocutaneous barrier could upregulate toll-like receptor (TLR) 2, 4, and 9 gene expression via the p38 mitogenactivated protein kinase pathway in cervical adenocarcinoma (HeLa) cells [24]. However, TLR4 was not upregulated by $T$. vaginalis in non-cancer human female genital tract epithelial cells [34].

\section{Cysteine proteinases of $T$. vaginalis. Possible target for chemotherapy and vaccine candidates}

More than 180 million people worldwide are infected annually by $T$. vaginalis [97]. Metronidazole has been the standard therapy for the treatment of trichomonosis [53]. Resistance to the drug has been reported both in vitro and clinically $[30,95]$, suggesting a need to develop sustainable control strategies such as vaccination and development of new anti-Trichomonas drugs for the control of this disease. Currently, there is little knowledge about $T$. vaginalis surface antigens, and hence the considerations for the development of a potential vaccine are limited [21]. Similarly, the development of alternative antimicrobial strategies targeting virulence factors or based on immunotherapeutic approaches [18] would also depend on detailed knowledge of the pathogen pathobiology and the host defense mechanisms. 
During infection with $T$. vaginalis, immunity has been difficult to achieve in vivo, since in humans, repeated infections with the parasite do not confer immune protection [52]. Despite this, antibodies have been found in the serum [98] and vaginal secretions of infected individuals [50,98] and a cell-mediated immune response is also involved [100].

A previous study demonstrated that intranasal immunization with the $62-\mathrm{kDa}$ proteinase of $T$. vaginalis with adjuvant confers protection in mice, suggesting that the levels of IgA are important in protective immune responses against T. vaginalis [47].

In addition, designing cysteine proteinase inhibitors as drugs could be another contribution to the control of the infections [77], but requires the knowledge of which CPs are essential to the parasites. Protease inhibitors have generated interest as therapies and have proven to be of great value in the control of parasitic diseases, including malaria [85], trypanosomiasis [20], and angiostrongylosis [68]. Progress in this area for trichomonosis has been minimal, but advances in the characterization of parasite proteases could expedite new drug discovery efforts. Recently, the $T$. vaginalis protein phosphatase 1 gamma (TvPP1 $\gamma$ ) has been considered a potential novel drug target for treatment of trichomonosis [73].

In most cases, understanding the role of trichomonal CPs has been limited by difficulties in obtaining enough quantity for protein purification and characterization, although recent advances have provided recombinant proteinase for more detailed study. Despite this, researchers have obtained important results that have led to a better knowledge of the parasite's pathogenesis [81].

\section{Conclusions}

It is evident that the pathogenicity of $T$. vaginalis is multifaceted. Despite the frequency of infection by $T$. vaginalis, basic components of the disease process are still unknown. Cysteine proteinases are key proteins in the metabolic process; the knowledge of the roles of some CPs in the onset of the infection are very important; it will be useful in order to develop targeted intervention strategies such as vaccines and drugs. A T. vaginalis vaccine and the identification of promising targets for drug development could provide short-term cures, reduce medical costs, and prevent sequel associated with pregnancy and infertility. More research is needed to improve our understanding of this parasite infection.

Acknowledgements. The authors thank Lic. Lázaro González for his assistance. We also thank Amelia Rodríguez for editorial assistance.

\section{References}

1. Afzan MY, Suresh K. 2012. Pseudocyst forms of Trichomonas vaginalis from cervical neoplasia. Parasitology Research, 111(1), 371-381.

2. Al-Mohammed HI, Hussein EM. 2006. Comparison between secretory leukocytic protease inhibitor and reactive nitrogen intermediates levels in cervicovaginal secretions from symptomatic and asymptomatic trichomoniasis Egyptians patients. Journal of the Egyptian Society of Parasitology, 36(3), 763-777.
3. Alderete JF, Benchimol M, Lehker MW, Crouch ML. 2002. The complex fibronectin-Trichomonas vaginalis interactions and Trichomonosis. Parasitology International, 51(3), 285-292.

4. Alderete JF, Newton E, Dennis C, Neale KA. 1991. Antibody in sera of patients infected with Trichomonas vaginalis is to trichomonad proteinases. Genitourinary Medicine, 67(4), 331-334.

5. Alderete JF, Newton E, Dennis C, Neale KA. 1991. The vagina of women infected with Trichomonas vaginalis has numerous proteinases and antibody to trichomonad proteinases. Genitourinary Medicine, 67(6), 469-474.

6. Alderete JF, O'Brien JL, Arroyo R, Engbring JA, Musatovova O, López O, Lauriano C, Nguyen J. 1995. Cloning and molecular characterization of two genes encoding adhesion proteins involved in Trichomonas vaginalis cytoadherence. Molecular Microbiology, 17(1), 69-83.

7. Alderete JF, Provenzano D. 1997. The vagina has reducing environment sufficient for activation of Trichomonas vaginalis cysteine proteinases. Genitourinary Medicine, 73(4), 291-296.

8. Alvarez-Sánchez ME, Ávila-González L, Becerril-García C, Fattel-Facenda LV, Ortega-López J, Arroyo R. 2000. A novel cysteine proteinase (CP65) of Trichomonas vaginalis involved in cytotoxicity. Microbial Pathogenesis, 28(4), 193-202.

9. Alvarez-Sánchez ME, Carvajal-Gámez BI, Solano-González E, Martínez-Benitez M, García AF, Alderete JF, Arroyo R. 2008. Polyamine depletion down-regulates expression of the Trichomonas vaginalis cytotoxic CP65, a $65-\mathrm{kDa}$ cysteine proteinase involved in cellular damage. International Journal of Biochemistry \& Cell Biology, 40(11), 2442-2451.

10. Alvarez-Sánchez ME, Solano-González E, Yañez-Gómez C, Arroyo R. 2007. Negative iron regulation of the CP65 cysteine proteinase cytotoxicity in Trichomonas vaginalis. Microbes and Infection, 9(14-15), 1597-1605.

11. Ardalan S, Lee BC, Garber GE. 2009. Trichomonas vaginalis: the adhesins AP51 and AP65 bind heme and hemoglobin. Experimental Parasitology, 121(4), 300-306.

12. Arroyo R, Alderete JF. 1989. Trichomonas vaginalis surface proteinase activity is necessary for parasite adherence to epithelial cells. Infection and Immunity, 57(10), 2991-2997.

13. Arroyo R, Alderete JF. 1995. Two Trichomonas vaginalis surface proteinases bind to host epithelial cells and are related to levels of cytoadherence and cytotoxicity. Archives of Medical Research, 26(3), 279-285.

14. Arroyo R, Engbring J, Alderete JF. 1992. Molecular basis of host epithelial cell recognition by Trichomonas vaginalis. Molecular Microbiology, 6(7), 853-862.

15. Arroyo R, González-Robles A, Martínez-Palomo A, Alderete JF. 1993. Signalling of Trichomonas vaginalis for amoeboid transformation and adhesion synthesis follows cytoadherence. Molecular Microbiology, 7(2), 299-309.

16. Bastida-Corcuera FD, Okumura C, Colocoussi A, Johnson PJ. 2005. Trichomonas vaginalis lipophosphoglycan mutants have reduced adherence and cytotoxicity to human ectocervical cells. Eukaryotic Cell, 4(11), 1951-1958.

17. Benchimol M, de Andrade Rosa I, da Silva Fontes R, Burla Dias AJ. 2008. Trichomonas adhere and phagocytose sperm cells: adhesion seems to be a prominent stage during interaction. Parasitology Research, 102(4), 597-604.

18. Brotz-Oesterhelt H, Sass P. 2010. Postgenomic strategies in antibacterial drug discovery. Future Microbiology, 5(10), 1553-1579. 
19. Carlton JM, Hirt RP, Silva JC, Delcher AL, Schatz M, Zhao Q, Wortman JR, Bidwell SL, Alsmark UC, Besteiro S, SicheritzPonten T, Noel CJ, Dacks JB, Foster PG, Simillion C, Van de Peer Y, Miranda-Saavedra D, Barton GJ, Westrop GD, Muller S, Dessi D, Fiori PL, Ren Q, Paulsen I, Zhang H, Bastida-Corcuera FD, Simoes-Barbosa A, Brown MT, Hayes RD, Mukherjee M, Okumura CY, Schneider R, Smith AJ, Vanacova S, Villalvazo M, Haas BJ, Pertea M, Feldblyum TV, Utterback TR, Shu CL, Osoegawa K, de Jong PJ, Hrdy I, Horvathova L, Zubacova Z, Dolezal P, Malik SB, Logsdon JM Jr, Henze K, Gupta A, Wang CC, Dunne RL, Upcroft JA, Upcroft P, White O, Salzberg SL, Tang P, Chiu CH, Lee YS, Embley TM, Coombs GH, Mottram JC, Tachezy J, Fraser-Liggett CM, Johnson PJ. 2007. Draft genome sequence of the sexually transmitted pathogen Trichomonas vaginalis. Science, 315(5809), 207-212.

20. Castro HC, Abreu PA, Geraldo RB, Martins RC, dos Santos R, Loureiro NI, Cabral LM, Rodrigues CR. 2011. Looking at the proteases from a simple perspective. Journal of Molecular Recognition, 24(2), 165-181.

21. Cudmore SL, Garber GE. 2010. Prevention or treatment: the benefits of Trichomonas vaginalis vaccine. Journal of Infection and Public Health, 3(2), 47-53.

22. Cuervo P, Cupolillo E, Britto C, González LJ, E Silva-Filho FC, Lopes LC, Domont GB, De Jesu JB. 2008. Differential soluble protein expression between Trichomonas vaginalis isolates exhibiting low and high virulence phenotypes. Journal of Proteomics, 71(1), 109-122.

23. Chang JH, Kim SK, Choi IH, Lee SK, Morio T, Chang EJ. 2006. Apoptosis of macrophages induced by Trichomonas vaginalis through the phosphorylation of p38 mitogenactivated protein kinase that locates at downstream of mitochondria-dependent caspase activation. International Journal of Biochemistry \& Cell Biology, 38(4), 638-647.

24. Chang JH, Park JY, Kim SK. 2006. Dependence on p38 MAPK signalling in the up-regulation of TLR2, TLR4 and TLR9 gene expression in Trichomonas vaginalis-treated HeLa cells. Immunology, 118(2), 164-170.

25. Chang JH, Ryang YS, Morio T, Lee SK, Chang EJ. 2004. Trichomonas vaginalis inhibits proinflammatory cytokine production in macrophages by suppressing NF-kappaB activation. Molecular Cell, 18(2), 177-185.

26. da Costa RF, de Souza W, Benchimol M, Alderete JF, Morgado-Diaz JA. 2005. Trichomonas vaginalis perturbs the junctional complex in epithelial cells. Cell Research, 15(9), 704-716.

27. Dailey DC, Chang TH, Alderete JF. 1990. Characterization of Trichomonas vaginalis haemolysis. Parasitology, 101(Pt 2), 171-175.

28. de Jesus JB, Cuervo P, Britto C, Saboia-Vahia L, Costa E, Silva-Filho F, Borges-Veloso A, Barreiros Petrópolis D, Cupolillo E, Barbosa Domont G. 2009. Cysteine peptidase expression in Trichomonas vaginalis isolates displaying highand low-virulence phenotypes. Journal of Proteome Research, 8(3), 1555-1564.

29. de Jesus JB, Cuervo P, Junqueira M, Britto C, Silva-Filho FC, Soares MJ, Cupolillo E, Fernandes O, Domont GB. 2007. A further proteomic study on the effect of iron in the human pathogen Trichomonas vaginalis. Proteomics, 7(12), 1961-1972.

30. Dunne RL, Dunn LA, Upcroft P, O'Donoghue PJ, Upcroft JA. 2003. Drug resistance in the sexually transmitted protozoan Trichomonas vaginalis. Cell Research, 13(4), 239-249.
31. Engbring JA, Alderete JF. 1998. Characterization of Trichomonas vaginalis AP33 adhesin and cell surface interactive domains. Microbiology, 144(Pt 11), 3011-3018.

32. Fichorova RN. 2009. Impact of T. vaginalis infection on innate immune responses and reproductive outcome. Journal of Reproductive Immunology, 83(1-2), 185-189.

33. Fichorova RN, Buck OR, Yamamoto HS, Fashemi T, Dawood HY, Fashemi B, Hayes GR, Beach DH, Takagi Y, Delaney ML, Nibert ML, Singh BN, Onderdonk AB. 2013. The villain team-up or how Trichomonas vaginalis and bacterial vaginosis alter innate immunity in concert. Sexually Transmitted Infections, 89(6), 460-466.

34. Fichorova RN, Lee Y, Yamamoto HS, Takagi Y, Hayes GR, Goodman RP, Chepa-Lotrea X, Buck OR, Murray R, Kula T, Beach DH, Singh BN, Nibert ML. 2012. Endobiont viruses sensed by the human host - beyond conventional antiparasitic therapy. PLoS One, 7(11), e48418.

35. Fichorova RN, Trifonova RT, Gilbert RO, Costello CE, Hayes GR, Lucas JJ, Singh BN. 2006. Trichomonas vaginalis lipophosphoglycan triggers a selective upregulation of cytokines by human female reproductive tract epithelial cells. Infection and Immunity, 74(10), 5773-5779.

36. Fiori PL, Rappelli P, Addis MF, Mannu F, Cappuccinelli P. 1997. Contact-dependent disruption of the host cell membrane skeleton induced by Trichomonas vaginalis. Infection and Immunity, 65(12), 5142-5148.

37. Fiori PL, Rappelli P, Rocchigiani AM, Cappuccinellim P. 1993. Trichomonas vaginalis haemolysis: evidence of functional pores formation on red cell membranes. FEMS Microbiology Letters, 109(1), 13-18.

38. Galetović A, Souza RT, Santos MR, Cordero EM, Bastos IM, Santana JM, Ruiz JC, Lima FM, Marini MM, Mortara RA, da Silveira JF. 2011. The repetitive cytoskeletal protein H49 of Trypanosoma cruzi is a calpain-like protein located at the flagellum attachment zone. PLoS One, 6(11), e27634.

39. Garber GE, Lemchuk-Favel LT. 1994. Analysis of the extracellular proteases of Trichomonas vaginalis. Parasitology Research, 80(5), 361-365.

40. García AF, Benchimol M, Alderete JF. 2005. Trichomonas vaginalis polyamine metabolism is linked to host cell adherence and cytotoxicity. Infection and Immunity, 73(5), 2602-2610.

41. García AF, Chang TH, Benchimol M, Klumpp DJ, Lehker MW, Alderete JF. 2003. Iron and contact with host cells induce expression of adhesins on surface of Trichomonas vaginalis. Molecular Microbiology, 47(5), 1207-1224.

42. Hansen G, Schwarzloh B, Rennenberg A, Heussler VT, Hilgenfeld R. 2011. The macromolecular complex of ICP and falcipain-2 from Plasmodium: preparation, crystallization and preliminary X-ray diffraction analysis. Acta Crystallographica Section F: Structural Biology and Crystallization Communications, 67(Pt 11), 1406-1410.

43. Harp DF, Chowdhury I. 2011. Trichomoniasis: evaluation to execution. European Journal of Obstetrics \& Gynecology and Reproductive Biology, 157(1), 3-9.

44. Hecht O, Van Nuland NA, Schleinkofer K, Dingley AJ, Bruhn H, Leippe M, Grötzinger J. 2004. Solution structure of the pore-forming protein of Entamoeba histolytica. Journal of Biological Chemistry, 279(17), 17834-17841.

45. Hernández-Gutíerrez R, Ávila-González L, Ortega-López J, Cruz-Talonia F, Gómez-Gutíerrez G, Arroyo R. 2004. Trichomonas vaginalis: characterization of a $39-\mathrm{kDa}$ cysteine 
proteinase found in patient vaginal secretions. Experimental Parasitology, 107(3-4), 125-135.

46. Hernández-Gutiérrez R, Ortega-López J, Arroyo R. 2003. A 39-kDa cysteine proteinase CP39 from Trichomonas vaginal$i s$, which is negatively affected by iron may be involved in trichomonal cytotoxicity. Journal of Eukaryotic Microbiology, 50(Suppl), 696-698.

47. Hernández HM, Figueredo M, Garrido N, Sánchez L, Sarracent J. 2005. Intranasal immunisation with a $62 \mathrm{kDa}$ proteinase combined with cholera toxin or $\mathrm{CpG}$ adjuvant protects against Trichomonas vaginalis genital tract infections in mice. International Journal for Parasitology, 35(13), 1333-1337.

48. Hernández H, Marcet R, Figueredo M, Garrido N, Sarracent J. 2008. Comparative study of epitopes recognized by two monoclonal antibodies that protects mice against Trichomonas vaginalis challenge. Experimental Parasitology, 118(4), 583-586.

49. Hernández H, Sariego I, Garber G, Delgado R, López O, Sarracent J. 2004. Monoclonal antibodies against a $62 \mathrm{kDa}$ proteinase of Trichomonas vaginalis decrease parasite cytoadherence to epithelial cells and confer protection in mice. Parasite Immunology, 26(3), 119-125.

50. Hernández HM, Sariego I, Alvarez AB, Marcet R, Vancol E, Alvarez A, Figueredo M, Sarracent J. 2011. Trichomonas vaginalis $62 \mathrm{kDa}$ proteinase as a possible virulence factor. Parasitology Research, 108(1), 241-245.

51. Hirt RP, de Miguel N, Nakjang S, Dessi D, Liu YC, Diaz N, Rappelli P, Acosta-Serrano A, Fiori PL, Mottram JC. 2011. Trichomonas vaginalis pathobiology new insights from the genome sequence. Advances in Parasitology, 77, 87-140.

52. Honigberg BM. 1987. Immunology of trichomonads, with emphasis on Trichomonas vaginalis. Acta Universitatis Carolinae - Biologica, 10, 321-336.

53. Huppert JS. 2009. Trichomoniasis in teens: an update. Current Opinion in Obstetrics \& Gynecology, 21(5), 371-378.

54. Huppert JS, Huang B, Chenm C, Dawood HY, Fichorova RN. 2013. Clinical evidence for the role of Trichomonas vaginalis in regulation of secretory leukocyte protease inhibitor in the female genital tract. Journal of Infectious Disease, 207(9), $1462-1470$

55. Kang JH, Song HO, Ryu JS, Shin MH, Kim JM, Cho YS, Alderete JF, Ahn MH, Min DY. 2006. Trichomonas vaginalis promotes apoptosis of human neutrophils by activating caspase- 3 and reducing Mcl-1 expression. Parasite Immunology, 28(9), 439-446.

56. Klemba M, Goldberg DE. 2002. Biological roles of proteases in parasitic protozoa. Annual Review of Biochemistry, 71, 275-305.

57. Kucknoor A, Mundodi V, Alderete JF. 2005. Trichomonas vaginalis adherence mediates differential gene expression in human vaginal epithelial cells. Cellular Microbiology, 7(6), 887-897.

58. Kucknoor AS, Mundodi V, Alderete JF. 2005. Adherence to human vaginal epithelial cells signals for increased expression of Trichomonas vaginalis genes. Infection and Immunity, 73(10), 6472-6478.

59. Kucknoor AS, Mundodi V, Alderete JF. 2007. The proteins secreted by Trichomonas vaginalis and vaginal epithelial cell response to secreted and episomally expressed AP65. Cellular Microbiology, 9(11), 2586-2597.
60. Kummer S, Hayes GR, Gilbert RO, Beach DH, Lucas JJ, Singh BN. 2008. Induction of human host cell apoptosis by Trichomonas vaginalis cysteine proteases is modulated by parasite exposure to iron. Microbial Pathogenesis, 44(3), 197203.

61. Lehker MW, Alderete JF. 1992. Iron regulates growth of Trichomonas vaginalis and the expression of immunogenic trichomonad proteins. Molecular Microbiology, 6(1), 123132.

62. Lehker MW, Alderete JF. 2000. Biology of trichomonosis. Current Opinion of Infectious Diseases, 13(1), 37-45.

63. Lehker MW, Arroyo R, Alderete JF. 1991. The regulation by iron of the synthesis of adhesins and cytoadherence levels in the protozoan Trichomonas vaginalis. Journal of Experimental. Medicine, 174(2), 311-318.

64. Lehker MW, Chang TH, Dailey DC, Alderete JF. 1990. Specific erythrocyte binding is an additional nutrient acquisition system for Trichomonas vaginalis. Journal of Experimental Medicine, 171(6), 2165-2170.

65. Lehker MW, Sweeney D. 1999. Trichomonad invasion of the mucous layer requires adhesins, mucinases, and motility. Sexually Transmitted Infections, 75(4), 231-238.

66. Leippe M, Bruhn H, Hecht O, Grötzinger J. 2005. Ancient weapons: the three-dimensional structure of amoebapore A. Trends Parasitology, 21(1), 5-7.

67. León-Sicairos CR, León-Felix J, Arroyo R. 2004. Tvcp12: a novel Trichomonas vaginalis cathepsin L-like cysteine proteinase-encoding gene. Microbiology, 150(Pt 5), 1131-1138.

68. Liu YH, Han YP, Li ZY, Wei J, He HJ, Xu CZ, Zheng HQ, Zhan XM, Wu ZD, Lv ZY. 2010. Molecular cloning and characterization of cystatin, a cysteine protease inhibitor, from Angiostrongylus cantonensis. Parasitology Research, 107(4), 915-922.

69. McClelland RS. 2008. Trichomonas vaginalis infection: Can we afford to do nothing? Journal of Infectious Disease, 197(4), 487-489.

70. Mendoza-López MR, Becerril-García C, Fattel-Facenda LV, Ávila-González L, Ruiz-Tachiquin ME, Ortega-López J, Arroyo R. 2000. CP30, a cysteine proteinase involved in Trichomonas vaginalis cytoadherence. Infection and Immunity, 68(9), 4907-4912.

71. Min DY, Hyun KH, Ryu JS, Ahn MH, Cho MH. 1998. Degradations of human immunoglobulins and hemoglobin by a $60 \mathrm{kDa}$ cysteine proteinase of Trichomonas vaginalis. Korean Journal of Parasitology, 36(4), 261-268.

72. Moreno-Brito V, Yáñez-Gómez C, Meza-Cervantez P, ÁvilaGonzález L, Rodríguez MA, Ortega-López J, González-Robles A, Arroyo RA. 2005. A Trichomonas vaginalis $120 \mathrm{kDa}$ protein with identity to hydrogenosome pyruvate:ferredoxin oxidoreductase is a surface adhesin induced by iron. Cellular Microbiology, 7(2), 245-258.

73. Muñoz C, Pérez M, Orrego PR, Osorio L, Gutíerrez B, Sagua H, Castillo JL, Martínez-Oyanedel J, Arroyo R, Meza-Cervantez P, da Silveira JF, Midlej V, Benchimol M, Cordero E, Morales P, Araya JE, González J. 2012. A protein phosphatase 1 gamma (PP1gamma) of the human protozoan parasite Trichomonas vaginalis is involved in proliferation and cell attachment to the host cell. International Journal for Parasitology, 42(8), 715-727.

74. Neale KA, Alderete JF. 1990. Analysis of the proteinases of representative Trichomonas vaginalis isolates. Infection and Immunity, 58(1), 157-162. 
75. Norbury LJ, Beckham S, Pike RN, Grams R, Spithill TW, Fecondo JV, Smooker PM. 2011. Adult and juvenile Fasciola cathepsin L proteases: different enzymes for different roles. Biochimie, 93(3), 604-611.

76. Ong SJ, Hsu HM, Liu HW, Chu CH, Tai JH. 2007. Activation of multifarious transcription of an adhesion protein ap65-1 gene by a novel Myb2 protein in the protozoan parasite Trichomonas vaginalis. Journal of Biological Chemistry, 282(9), 6716-6725.

77. Peng J, Yang Y, Feng X, Cheng G, Lin J. 2010. Molecular characterizations of an inhibitor of apoptosis from Schistosoma japonicum. Parasitology Research, 106(4), 967-976.

78. Provenzano D, Alderete JF. 1995. Analysis of human immunoglobulin-degrading cysteine proteinases of Trichomonas vaginalis. Infection and Immunity, 63(9), 3388-3395.

79. Quintas-Granados LI, Orozco E, Brieba LG, Arroyo R, Ortega-López J. 2009. Purification, refolding and autoactivation of the recombinant cysteine proteinase EhCP112 from Entamoeba histolytica. Protein Expression Purification, 63(1), 26-32.

80. Ramón-Luing LA, Rendón-Gandarilla FJ, Cárdenas-Guerra RE, Rodríguez-Cabrera NA, Ortega-López J, Ávila-González L, Angel-Ortiz C, Herrera-Sánchez CN, Mendoza-García M, Arroyo R. 2010. Immunoproteomics of the active degradome to identify biomarkers for Trichomonas vaginalis. Proteomics, 10(3), 435-444.

81. Ramón-Luing LA, Rendón-Gandarilla FJ, Puente-Rivera J, Ávila-González L, Arroyo R. 2011. Identification and characterization of the immunogenic cytotoxic TvCP39 proteinase gene of Trichomonas vaginalis. International Journal of Biochemistry \& Cell Biology, 43(10), 1500-1511.

82. Rebello KM, Côrtes LM, Pereira BA, Pascarelli BM, CôrteReal S, Finkelstein LC, Pinho RT, d'Avila-Levy CM, Alves CR. 2009. Cysteine proteinases from promastigotes of Leishmania (Viannia) braziliensis. Parasitology Research, 106(1), 95-104.

83. Rendon-Gandarilla FJ, Ramón-Luing LD, Ortega-López J, Rosa de Andrade I, Benchimol M, Arroyo R. 2013. The TvLEGU-1, a legumain-like cysteine proteinase, plays a key role in Trichomonas vaginalis cytoadherence. BioMed Research International, 2013, 561979.

84. Rendon-Maldonado JG, Espinosa-Cantellano M, GónzalezRobles A, Martínez-Palomo A. 1998. Trichomonas vaginalis: in vitro phagocytosis of lactobacilli, vaginal epithelial cells, leukocytes, and erythrocytes. Experimental Parasitology, 89(2), 241-250.

85. Rosenthal PJ. 2011. Falcipains and other cysteine proteases of malaria parasites. Advances in Experimental Medicine and Biology, 712, 30-48.

86. Ryu JS, Choi HK, Min DY, Ha SE, Ahn MH. 2001. Effect of iron on the virulence of Trichomonas vaginalis. Journal of Parasitology, 87(2), 457-460.

87. Scott DA, North MJ, Coombs GH. 1995. Trichomonas vaginalis: amoeboid and flagellated forms synthesize similar proteinases. Experimental Parasitology, 80(2), 345-348.
88. Schwebke JR, Burgess D. 2004. Trichomoniasis. Clinical Microbiology Reviews, 17(4), 794-803.

89. Smooker PM, Jayaraj R, Pike RN, Spithill TW. 2010. Cathepsin B proteases of flukes: the key to facilitating parasite control? Trends in Parasitology, 26(10), 506-514.

90. Solano-González E, Burrola-Barraza E, León-Sicairos C, Ávila-González L, Gutiérrez-Escolano L, Ortega-López J, Arroyo R. 2007. The trichomonad cysteine proteinase TVCP4 transcript contains an iron-responsive element. FEBS Letters, 581(16), 2919-2928.

91. Sommer U, Costello CE, Hayes GR, Beach DH, Gilbert RO, Lucas JJ, Singh BN. 2005. Identification of Trichomonas vaginalis cysteine proteases that induce apoptosis in human vaginal epithelial cells. Journal of Biological Chemistry, 280(25), 23853-23860.

92. Sood S, Kapil A. 2008. An update on Trichomonas vaginalis. Indian Journal of Sexually Transmitted Diseases, 29(1), 7-14.

93. Sorvillo F, Kerndt P. 1998. Trichomonas vaginalis and amplification of HIV-1 transmission. Lancet, 351(9097), 213-214.

94. Torres-Romero JC, Arroyo R. 2009. Responsiveness of Trichomonas vaginalis to iron concentrations: evidence for a post-transcriptional iron regulation by an IRE/IRP-like system. Infection Genetics and Evolution, 9(6), 1065-1074.

95. Upcroft JA, Dunn LA, Wal T, Tabrizi S, Delgadillo-Correa MG, Johnson PJ, Garland S, Siba P, Upcroft P. 2009. Metronidazole resistance in Trichomonas vaginalis from highland women in Papua New Guinea. Sexual Health, 6(4), 334-338.

96. Vazquez-Carrillo LI, Quintas-Granados LI, Arroyo R, Mendoza-Hernández G, González-Robles A, Carvajal-Gámez BI, Álvarez-Sánchez ME. 2011. The effect of $\mathrm{Zn}^{2+}$ on prostatic cell cytotoxicity caused by Trichomonas vaginalis. Journal of Integrated Omics, 1(2), 198-210.

97. Wendel KA. 2003. Trichomoniasis: What's new? Current Infectious Disease Reports, 5(2), 129-134.

98. Yadav M, Dubey ML, Gupta I, Malla N. 2007. Cysteine proteinase $30(\mathrm{CP} 30)$ and antibody response to CP30 in serum and vaginal washes of symptomatic and asymptomatic Trichomonas vaginalis-infected women. Parasite Immunology, 29(7), 359-365.

99. Yadav M, Dubey ML, Gupta I, Bhatti G, Malla N. 2007. Cysteine proteinase 30 in clinical isolates of $T$. vaginalis from symptomatic and asymptomatic infected women. Experimental Parasitology, 116(4), 399-406.

100. Yano A, Yui K, Aosai F, Kojima S, Kawana T, Ovary Z. 1983. Immune response to Trichomonas vaginalis. IV. Immunochemical and immunobiological analyses of $T$. vaginalis antigen. International Archives of Allergy and Applied Immunology, 72(2), 150-157.

101. Zariffard MR, Harwani S, Novak RM, Graham PJ, Ji X, Spear GT. 2004. Trichomonas vaginalis infection activates cells through toll-like receptor. Clinical Immunology, 111(1), 103-107. 
Cite this article as: Hernández HM, Marcet R \& Sarracent J: Biological roles of cysteine proteinases in the pathogenesis of Trichomonas vaginalis. Parasite, 2014, 21, 54.

\section{- PARASTE}

An international open-access, peer-reviewed, online journal publishing high quality papers on all aspects of human and animal parasitology

Reviews, articles and short notes may be submitted. Fields include, but are not limited to: general, medical and veterinary parasitology; morphology, including ultrastructure; parasite systematics, including entomology, acarology, helminthology and protistology, and molecular analyses; molecular biology and biochemistry; immunology of parasitic diseases; host-parasite relationships; ecology and life history of parasites; epidemiology; therapeutics; new diagnostic tools.

All papers in Parasite are published in English. Manuscripts should have a broad interest and must not have been published or submitted elsewhere. No limit is imposed on the length of manuscripts.

Parasite (open-access) continues Parasite (print and online editions, 1994-2012) and Annales de Parasitologie Humaine et Comparée (1923-1993) and is the official journal of the Société Française de Parasitologie. 